DOI 10. 18307/2016. 0618

(c) 2016 by Journal of Lake Sciences

\title{
新疆艾比湖湿地土壤水盐空间变异性分析
}

\author{
赵明亮 ${ }^{1,2}$, 李艳红 ${ }^{1,2 * *}$, 李发东 ${ }^{1,2,3}$ \\ ( 1 : 新疆师范大学地理科学与旅游学院, 乌鲁木齐 830054$)$ \\ ( 2 : 新疆维吾尔自治区重点实验室; 新疆干旱区湖泊环境与资源实验室,乌鲁木齐 830054) \\ (3: 中国科学院地理科学与资源研究所, 北京 100101)
}

\begin{abstract}
摘 要: 为揭示艾比湖湿地土壤退化程度空间分布特征, 在离艾比湖湖滨 $5 \sim 15 \mathrm{~km}$, 绕湖一周 $160 \mathrm{~km}$ 范围内, 以湖心质 点为中心, 将艾比湖划分为东北、东南、西南、西北 4 个区域, 采用传统统计学和地统计学相结合的方法对表层 $(0 \sim 20 \mathrm{~cm})$ 土壤盐分、含水量与 $\mathrm{pH}$ 的空间分异特征进行研究.结果表明:绕湖一周不同区域的土壤盐分均属中等变异强度; 土㝇含水 量在西北部属强变异性, 而东北、东南和西南部均属中等变异强度; 土壤 $\mathrm{pH}$ 在不同区域内均属弱变异强度.绕湖一周除西 北部土壤盐分的半方差理论模型较符合球状模型外, 其它区域土壤盐分、含水量和 $\mathrm{pH}$ 均符合高斯模型; 受结构性因素影 响, 不同区域土壤盐分、含水量和 $\mathrm{pH}$ 均具有较强的空间相关性; 西南部土壤盐分、含水量和 $\mathrm{pH}$ 的 Moran's I 系数比其它区 域的波动大,表明空间相关性较强.艾比湖湿地常年大风、干旱、缺水及沙化盐化的自然因素与引水围堰、种植耐盐碱植物 的人为活动造成了采样区表层土壤盐分、含水量和 $\mathrm{pH}$ 的空间分布多呈现不规则条带状格局. 艾比湖湿地土壤以盐土为 主,重度盐化土次之,土壤盐渍化日益严重.
\end{abstract}

关键词: 艾比湖湿地;水盐;半方差;空间变异性

\section{Analysis of the spatial variability of soil moisture and salinity in Ebinur Lake wetlands, Xin- jiang}

\author{
ZHAO Mingliang ${ }^{1,2}$, LI Yanhong ${ }^{1,2 * *}$ \& LI Fadong ${ }^{1,2,3}$ \\ (1: College of Geographic Science and Tourism, Xinjiang Normal University, Urumqi 830054,P.R.China) \\ (2: Key Laboratory of Xinjiang Uygur Autonomous Region; Xinjiang Laboratory of Lake Environment and Resources in Arid \\ Area, Urumqi 830054, P.R.China) \\ (3: Institute of Geographic Sciences and Natural Resources Research, Beijing 100101, P.R.China)
}

\begin{abstract}
Systematic research of soil water and salt is commonly lack in previous studies for the Lake Ebinur, thus in this study, in order to reveal the spatial distribution characteristics of soil degradation degree in the Lake Ebinur wetland, by taking the lake side of a distance to the Lake Ebinur 5-15 km, a circle area of $160 \mathrm{~km}^{2}$ as research area. The spatial variability of soil salinity, $\mathrm{pH}$ and moisture in the surface layer $(0-20 \mathrm{~cm})$ of in the circle sampling area of Lake Ebinur was analyzed by using traditional statistics and geo-statistics. The results indicated that the variation in salinity was moderate in the different directions. The soil moisture in the Northeast, Southeast and Southwest belongs to the medium variation intensity, while the northwest belongs to strong variability. The soil $\mathrm{pH}$ of different directions has weak variation. Except that the soil salinity of northwest follows with the spherical model, soil salinity, water content and $\mathrm{pH}$ in other different directions were in line with the Gaussian model. Soil salinity, water content and $\mathrm{pH}$ of different directions showed strong spatial autocorrelation, which were mainly affected by structural factors. Moran's I coefficient analysis proved that soil salinity in the southwest, water content and $\mathrm{pH}$ was stronger in spatial correlation than that in the other directions. The natural factors including winds, drought, water scarcity, desertification, salinization, and human activities including diversion cofferdam, planting drought-resistant and salt-tolerant plants, were contributed to sampling area of Lake Ebinur
\end{abstract}

* 自治区科技计划项目(201433115) 一一艾比湖退化湿地典型植被生态恢复技术集成与示范研究、国家自然科学基 金项目 (41561104) 和新疆师范大学地理学博士点支撑学科项目 (XJNU-DL-201506) 联合资助. 2015-11-03 收稿; 2016-01 -04 收修改稿.赵明亮( 1991 ), 男,硕士研究生;E-mail:1547884890@ qq.com.

** 通信作者;E-mail:lyh0704@ 126.com. 
wetland spatial distribution of surface soil salinity, water content and $\mathrm{pH}$. Soil in the Lake Ebinur wetland is mainly of saline-based type, followed by the type of severe salinization and more serious salinization.

Keywords: Lake Ebinur wetland; moisture and salt; semi-variance; spatial change ability

土壤水盐状况及其空间变异性研究是土壤科学研究的热点之一, 是土壤盐渍化防控和盐碱土地资源利 用的重要基础 ${ }^{[1]}$. 国外 Jordán 等对干旱与半干旱地区土壤盐分在地质和环境因素影响下的空间变化进行研 究 ${ }^{[2]}$; Herbst 等用地统计学模拟和实测模拟对小尺度集水区的土壤水分空间变异进行了研究 ${ }^{[3]}$; Cemek 等对 土耳其北部的冲积平原农田土壤盐分空间变异的研究得出, 土壤盐分的空间变异性主要由地下水位、排水、 灌溉系统以及微地形等外因控制 ${ }^{[4]}$. 在国内一些学者对黄河三角洲地区 ${ }^{[5]}$ 、张掖绿洲 ${ }^{[6]}$ 、辽河三角洲不同植 被类型 ${ }^{[7]}$ 、塔里木河上游典型绿洲 ${ }^{[8]}$ 等地的土壤水盐状况及空间异质性进行了研究, 认为盐分、含水量的空 间变异性与自然环境和人为因素有关.

艾比湖湿地国家自然保护区是干旱区荒漠生态系统的典型代表, $1950 \mathrm{~s}$, 艾比湖面积有 $1200 \mathrm{~km}^{2}$, 如今湖 面已经萎缩至 $500 \mathrm{~km}^{2}$ 左右, 已成为困扰新疆的第二大生态问题 ${ }^{[9]}$, 湖滨地区荒漠化程度加剧, 成为中国西 部沙尘暴主要策源地之一, 直接威胁到天山北坡经济带的可持续发展和新亚欧大陆桥的安全运行. 近 10 年 关于艾比湖湿地的盐分、水分、养分等土壤理化性质 ${ }^{[10]}$ 、土壤酶活性 ${ }^{[11]}$ 、土壤呼吸 ${ }^{[12]}$ 、植物群落 ${ }^{[13]}$ 以及其之 间的相关分析的研究主要集中在艾比湖湖周到绿洲农田、博河下游、精河下游和精河围堰区以及阿其克苏 河下游等地, 缺乏对艾比湖绕湖一周土壤水盐的系统研究, 因此本文选择离艾比湖湖滨 $5 \sim 15 \mathrm{~km}$, 绕湖一周 $160 \mathrm{~km}$ 范围内为研究区, 对艾比湖湿地不同区域的土壤水盐特征及土壤退化程度进行分析, 旨在为保护艾 比湖地区生态环境安全提供可靠的理论依据.

\section{1 材料与方法}

\section{1 研究区概况}

艾比湖湿地国家级自然保护区 $\left(44^{\circ} 30^{\prime} \sim 45^{\circ} 09^{\prime} \mathrm{N}, 82^{\circ} 36^{\prime} \sim 82^{\circ} 50^{\prime} \mathrm{E}\right)$ 位于新疆维吾尔自治区精河县境 内, 是新疆第一大咸水湖. 年平均气温 $5^{\circ} \mathrm{C}$, 年平均降水量 $100 \mathrm{~mm}$ 左右, 年蒸发量 $1600 \mathrm{~mm}$, 属于典型温带大 陆性干旱气候. 1972-2011 年期间, 艾比湖的面积在不断缩小, 共缩小 $115.03 \mathrm{~km}^{2[11]} .2012-2015$ 年期间, 本课题组通过对艾比湖湿地采样调研, 发现艾比湖湿地盐化沙化加剧, 土壤平均粒径在 $2.63 \sim 6.51 \mu \mathrm{m}$ 之 间, 土壤有机质含量在 $0.0003 \% \sim 2.3401 \%$ 之间, 土壤盐分呈现表聚性, 高达 $85.32 \mathrm{~g} / \mathrm{kg}, \mathrm{pH}$ 值在 7.52 9.29之 间. 本文选择在离艾比湖湖滨 5 15 km, 绕湖一周 $160 \mathrm{~km}$ 范围内, 以湖心质点 $\left(44^{\circ} 52^{\prime} 32.77^{\prime \prime} \mathrm{N}, 83^{\circ} 2^{\prime} 18.34^{\prime \prime} \mathrm{E}\right)$ 为 中心,将艾比湖划分为东北、东南、西南、西北 4 个区域 (图 1). 其中北部的科克巴斯陶管护站区域海拔低 $(189 \mathrm{~m})$, 有天然泉水外流; 东北部桑德库木管护站和奎屯河下游地区土壤质地多为沙土, 土壤沙化严重, 主 要植被类型为梭梭; 东南部鸟鸟管护站、鸭子湾管护站主要植被分布类型有胡杨、盐角草等耐盐碱植物, 其 中沙泉子从 2013 年起采用滴管方式实施梭梭林人工种植恢复, 梭梭林恢复面积为 $7.3 \times 10^{6} \mathrm{~m}^{2}$; 西南部在 2002 年引精河水, 实施围堰和土壤改良工程, 现芦苇湿地恢复面积约 $2.6 \times 10^{6} \mathrm{~m}^{2}$, 博河下游采样区土壤质地 多为石砾, 优势种为碱蓬; 西北部受阿拉山口大风影响, 全年 8 级以上大风 $165 \mathrm{~d}$, 最大风速可达 $55 \mathrm{~m} / \mathrm{s}$, 植 物覆盖度极低,盐分含量高; 在研究区北部地区有牧民进行季节性放牧.

\section{2 研究方法}

课题组分别在 2013、2014 和 2015 年的 8 月沿着艾比湖湿地国家自然保护区管护站、博尔塔拉河、精河、 阿奇克苏河、奎屯河等绕湖一周 $160 \mathrm{~km}$ 范围内, 设置 73 个样地, 记录各样地的海拔、经纬度、植被类型和土 壤质地等要素. 共获取 73 个剖面, 每个剖面取表层 ( $0 \sim 20 \mathrm{~cm}$ ) 土样, 并用 GPS 定位(图 1). 将土壤样品带回 实验室, 进行自然风干、磨碎, 过 $2 \mathrm{~mm}$ 篮, 制备 $1: 5$ 的土水质量比浸提液, 测定土壤全盐含量 ${ }^{[15]}$; 浸提液 $\mathrm{pH}$ 值采用 HANNA 公司 $\mathrm{pH}$ 电极 ( $\mathrm{pH} 211$ Microprocessor $\mathrm{pH}$ Meter) 进行测定; 土壤含水量采用烘干法测定. 根据 新疆土壤盐碱化的分级标准 ${ }^{[16]}$, 将土壤分为非盐化土 (土壤盐分 $<3 \mathrm{~g} / \mathrm{kg}$ )、轻盐化土 (土壤盐分 $3 \sim 6 \mathrm{~g} / \mathrm{kg}$ )、 中度盐化土 (土壤盐分 $6 \sim 10 \mathrm{~g} / \mathrm{kg}$ )、重度盐化土 (土壤盐分 $10 \sim 20 \mathrm{~g} / \mathrm{kg}$ ) 和盐土 (土壤盐分 $>20 \mathrm{~g} / \mathrm{kg}$ ), 根据此 分级标准确定含盐量级别. 采用 Excel 对数据进行经典统计, 运用 GS +9.0 进行半方差函数计算, Moran's I 系数 
分析,Kriging 插值以及空间分布图利用 ArcGIS 10.0 软件绘制, 相关性分析采用 SPSS 19.0 软件.

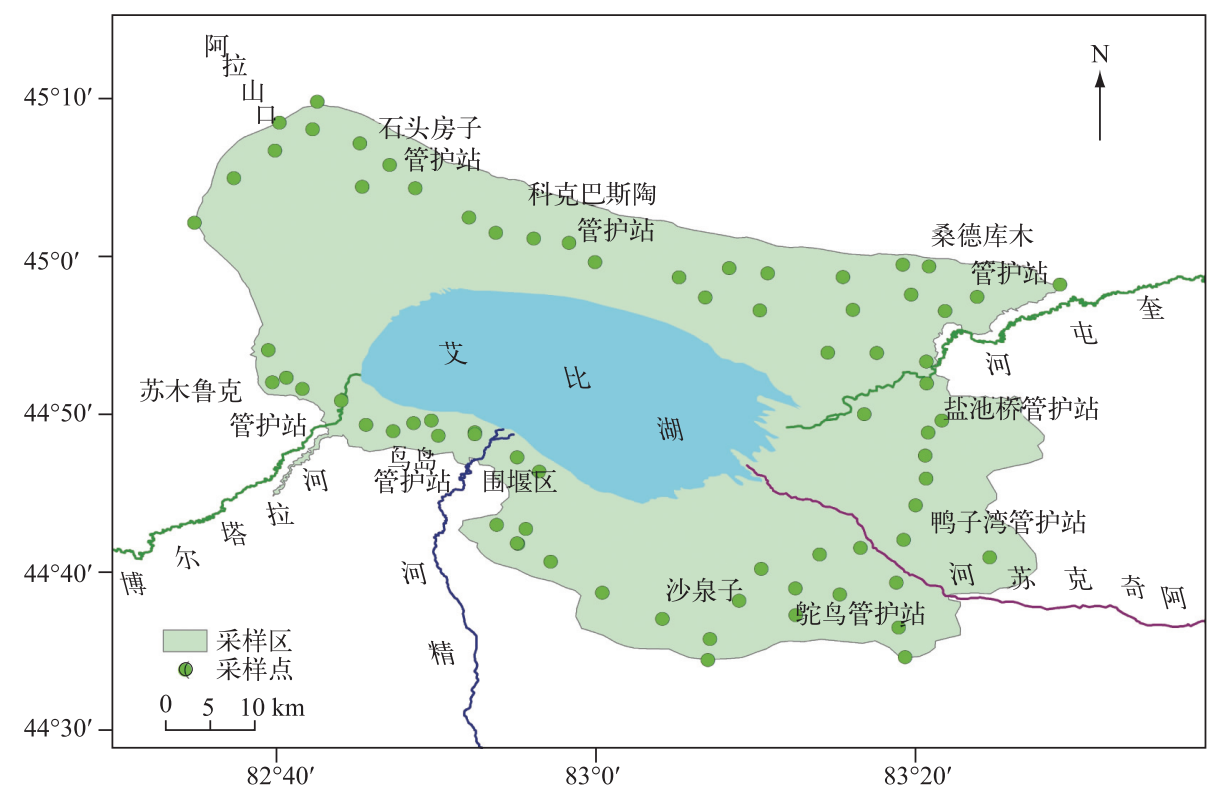

图 1 研究区示意图

Fig.1 Research area schematic drawing

\section{2 结果与分析}

\section{1 土壤盐分、含水量与 $\mathrm{pH}$ 描述性统计}

对不同区域表层 $(0 \sim 20 \mathrm{~cm})$ 土壤盐分、含水量和 $\mathrm{pH}$ 进行描述性统计分析 (表 1) 可知, 盐分平均含量由 大到小表现为西北部>东南部>西南部>东北部; 由于采样期正值旱季, 水分蒸发量强, 土壤含水量低, 其中东 南部含水量最小 $(26.454 \mathrm{~g} / \mathrm{kg})$, 东北部含水量最大 $(68.625 \mathrm{~g} / \mathrm{kg})$; 土壤 $\mathrm{pH}$ 平均值从大到小表现为西北部> 西南部>东南部>东北部, 且不同区域 $\mathrm{pH}$ 最大值均超过 9.0, 这说明该采样区在不同区域上土壤呈现出一定 程度的碱化趋势.

按照变异系数划分等级,当 $C V<10 \%$ 为弱变异性; $10 \%<C V<100 \%$ 时为中等变异性; $C V>100 \%$ 时为强变 异性 ${ }^{[17]}$. 不同区域土壤盐分均属于中等变异强度; 东北部、东南部、西南部的土壤含水量属于中等变异强 度,而西北部变异系数达到 1.087 , 属于强变异性; 不同区域土壤 $\mathrm{pH}$ 均属于弱变异强度; 且同一区域上的土 壤含水量变异系数均大于盐分和 $\mathrm{pH}$ 值 (表 1 ). 一般变异函数的计算要求数据符合正态分布, 否则可能存在 比例效应 ${ }^{[18]}$, 对数据进行 Komlogorow-Smirnow 法进行正态检验 $(P<0.05)$, 发现西南部土壤盐分与西北部土 壤含水量不符合正态分布, 经对数转化后呈正态分布, 变异函数计算采用的数据为对数转化后的数据.

\section{2 土壤盐分、含水量与 $\mathrm{pH}$ 值的半方差函数分析}

根据半方差函数理论及计算模型 ${ }^{[19-20]}$ 获得了研究区的土壤盐分、含水量与 $\mathrm{pH}$ 的半方差函数模型及其 相关参数 (表 2), 可以发现除了西北部土壤盐分符合球状模型外, 其它不同区域土壤盐分、含水量和 $\mathrm{pH}$ 半 方差理论模型都符合高斯模型，且不同区域土壤盐分、含水量与 $\mathrm{pH}$ 的块金值/基台值变化范围小于 0.25 ,均 表现为较强的空间相关性,这表明不同区域上的土壤盐分、含水量与 $\mathrm{pH}$ 的空间分布主要是受结构性因素 (如地形、土壤类型、母质、气候等) 影响, 其中盐分变异程度表现为西南部>东南部>东北部>西北部, 含水量 变异程度表现为东北部>东南部>西南部>西北部, $\mathrm{pH}$ 变异程度表现为西南部>东南部>东北部>西北部. 分 维数 $D$ 表示变异函数曲线的曲率大小, 可确定空间结构复杂程度. 不同区域上的土壤盐分、含水量与 $\mathrm{pH}$ 的 分维数范围在 $1.033 \sim 1.881$ 之间, 其中东北部、东南部和西南部土壤盐分、含水量和 $\mathrm{pH}$ 的分维数均高于西 
表 1 土壤盐分、含水率和 $\mathrm{pH}$ 的统计特征值 ${ }^{*}$

Tab.1 Statistical charactristic values of soil salinity, moisture and $\mathrm{pH}$

\begin{tabular}{lccccccc}
\hline 土壤特征值 & 区域 & 最大值 & 最小值 & 平均值 & 标准差 & 变异系数 & 分布类型 \\
\hline 盐分/ & 东北部 & 17.447 & 2.071 & 7.814 & 3.997 & 0.511 & $\mathrm{~N}$ \\
$(\mathrm{~g} / \mathrm{kg})$ & 东南部 & 35.057 & 1.485 & 15.263 & 10.651 & 0.697 & $\mathrm{~N}$ \\
& 西南部 & 32.530 & 2.934 & 10.676 & 6.740 & 0.631 & $\mathrm{LN}$ \\
& 西北部 & 38.261 & 9.712 & 21.069 & 8.511 & 0.404 & $\mathrm{~N}$ \\
含水量/ & 东北部 & 134.340 & 4.829 & 68.625 & 44.255 & 0.645 & $\mathrm{~N}$ \\
$(\mathrm{~g} / \mathrm{kg})$ & 东南部 & 80.673 & 4.408 & 26.454 & 25.768 & 0.974 & $\mathrm{~N}$ \\
& 西南部 & 132.100 & 4.669 & 57.323 & 41.411 & 0.722 & $\mathrm{~N}$ \\
$\mathrm{pH}$ 值 & 西北部 & 205.758 & 4.342 & 51.704 & 56.201 & 1.087 & $\mathrm{LN}$ \\
& 东北部 & 9.012 & 7.470 & 8.318 & 0.454 & 0.054 & $\mathrm{~N}$ \\
& 东南部 & 9.100 & 7.547 & 8.491 & 0.507 & 0.059 & $\mathrm{~N}$ \\
& 西南部 & 9.007 & 7.844 & 8.520 & 0.436 & 0.051 & $\mathrm{~N}$ \\
& 西北部 & 9.298 & 7.828 & 8.789 & 0.435 & 0.050 & $\mathrm{~N}$ \\
\hline
\end{tabular}

* $\mathrm{N}$ 表示对数分布 (normal distribution), LN 表示对数正态分布(Logarithmic normal distribution); 变异系数无单位.

北部,且相差较大,这说明前三者的空间结构要比西北部较为复杂,这可能是由地形、母质、气候、土壤类型 等导致的. 从自相关距看,变程反应区域化变量空间相关范围的大小,与观测尺度以及取样尺度上影响土壤 水盐的各种生态过程的相互作用有关. 不同区域上的土壤盐分的自相关距变化范围在 7320 28450 m 之间, 含水量自相关距变化范围在 3560 21940 m 之间, $\mathrm{pH}$ 自相关距变化范围在 4420 27220 m 之间,且西南部土 壤盐分空间自相关距要明显小于其它 3 个区域,含水量和 $\mathrm{pH}$ 表现出西北部明显小于其它 3 个区域, 这是由 于西南部进行了引水围堰工程, 西北部大风盛行以及放牧等导致土壤盐分、含水量和 $\mathrm{pH}$ 的变程较小.

\section{表 2 土壤盐分、含水量与 $\mathrm{pH}$ 的半方差函数类型及其参数 ${ }^{*}$}

Tab.2 Types of semi-variance model and their parameters for soil salinity, moisture and $\mathrm{pH}$

\begin{tabular}{lccccccccc}
\hline 土壤特征 & 区域 & 理论模型 & $C_{0}$ & $C_{0}+C$ & $C_{0} /\left(C_{0}+C\right)$ & 自相关距/m & $R^{2}$ & $R S S$ & $D($ 分维数) \\
\hline 盐分/ & 东北部 & 高斯 & 0.085 & 0.769 & 0.111 & 14770 & 0.894 & 0.012 & 1.552 \\
$(\mathrm{~g} / \mathrm{kg})$ & 东南部 & 高斯 & 0.662 & 3.254 & 0.203 & 26630 & 0.692 & 0.222 & 1.827 \\
& 西南部 & 高斯 & 0.094 & 0.428 & 0.220 & 7320 & 0.342 & 0.403 & 1.881 \\
& 西北部 & 球状 & 0.001 & 0.376 & 0.003 & 28450 & 0.847 & 0.007 & 1.076 \\
含水量/ & 东北部 & 高斯 & 0.428 & 1.871 & 0.229 & 12240 & 0.655 & 0.352 & 1.679 \\
$(\mathrm{~g} / \mathrm{kg})$ & 东南部 & 高斯 & 0.451 & 2.05 & 0.220 & 18410 & 0.835 & 0.107 & 1.727 \\
& 西南部 & 高斯 & 0.142 & 2.294 & 0.062 & 21940 & 0.730 & 0.821 & 1.688 \\
& 西北部 & 高斯 & 0.001 & 0.617 & 0.002 & 3560 & 0.461 & 0.219 & 1.135 \\
$\mathrm{pH}$ & 东北部 & 高斯 & $3.40 \mathrm{E}-04$ & $5.230 \mathrm{E}-03$ & 0.065 & 14670 & 0.772 & $1.548 \mathrm{E}-06$ & 1.457 \\
& 东南部 & 高斯 & $8.30 \mathrm{E}-04$ & $1.120 \mathrm{E}-02$ & 0.074 & 27220 & 0.639 & $3.845 \mathrm{E}-06$ & 1.562 \\
& 西南部 & 高斯 & 0.001 & $4.320 \mathrm{E}-03$ & 0.231 & 11370 & 0.580 & $1.317 \mathrm{E}-05$ & 1.703 \\
& 西北部 & 高斯 & $1.00 \mathrm{E}-06$ & $2.712 \mathrm{E}-03$ & 0.0004 & 4420 & 0.782 & $1.418 \mathrm{E}-06$ & 1.033 \\
\hline
\end{tabular}

$* C_{0}$ 为块金值, $C_{0}+C$ 为基台值, $R S S$ 为残差平方和.

\section{3 土壤盐分、含水量与 $\mathrm{pH}$ 的 Moran's I 系数分析}

Moran's I 系数可定量描述研究变量在空间上的依赖关系. $I$ 的取值为 $-1 \sim 1, I>0$ 表示变量在空间上呈现 正相关; $I<0$ 表示研究变量在空间上呈现负相关; $I=0$ 表示研究变量在空间依赖性小或空间随机变异较大. 将 Moran's I 系数与滞后距离尺度相结合, 便可得到不同尺度下空间相关关系变化, 从而可以看出空间相关 性随尺度的变化 ${ }^{[21-22]}$. 东北部土壤盐分、含水量和 $\mathrm{pH}$ 的空间距离分别在 3487.782 、7847.509 和3487.782 $\mathrm{m}$ 表 现出强的正相关性, 随着距离增大, 正相关性减弱负相关性增强, 空间距离均增加到 $12207.238 \mathrm{~m}$ 时负相关 
性达最大, 分别为 $-0.456 、-0.385 、-0.273$, 此后随着空间距离增大负相关性也逐渐减弱 (图 2). 东南部和西 北部土壤盐分、含水量和 $\mathrm{pH}$ 随距离增加与东北部有相似的 Moran's I 系数变化趋势, 但也有不同, 其中西北 部的含水量随着距离的增加均没有达到负相关性. 西南部土壤盐分、含水量和 $\mathrm{pH}$ 相关性相对较强 ( $I$ 介于 $-0.921 \sim 1.300$ 之间), Moran's I 系数波动均较大, 空间相关性较强, 这与气候、地貌、微地形、土壤类型和人为 活动等因素密切相关.
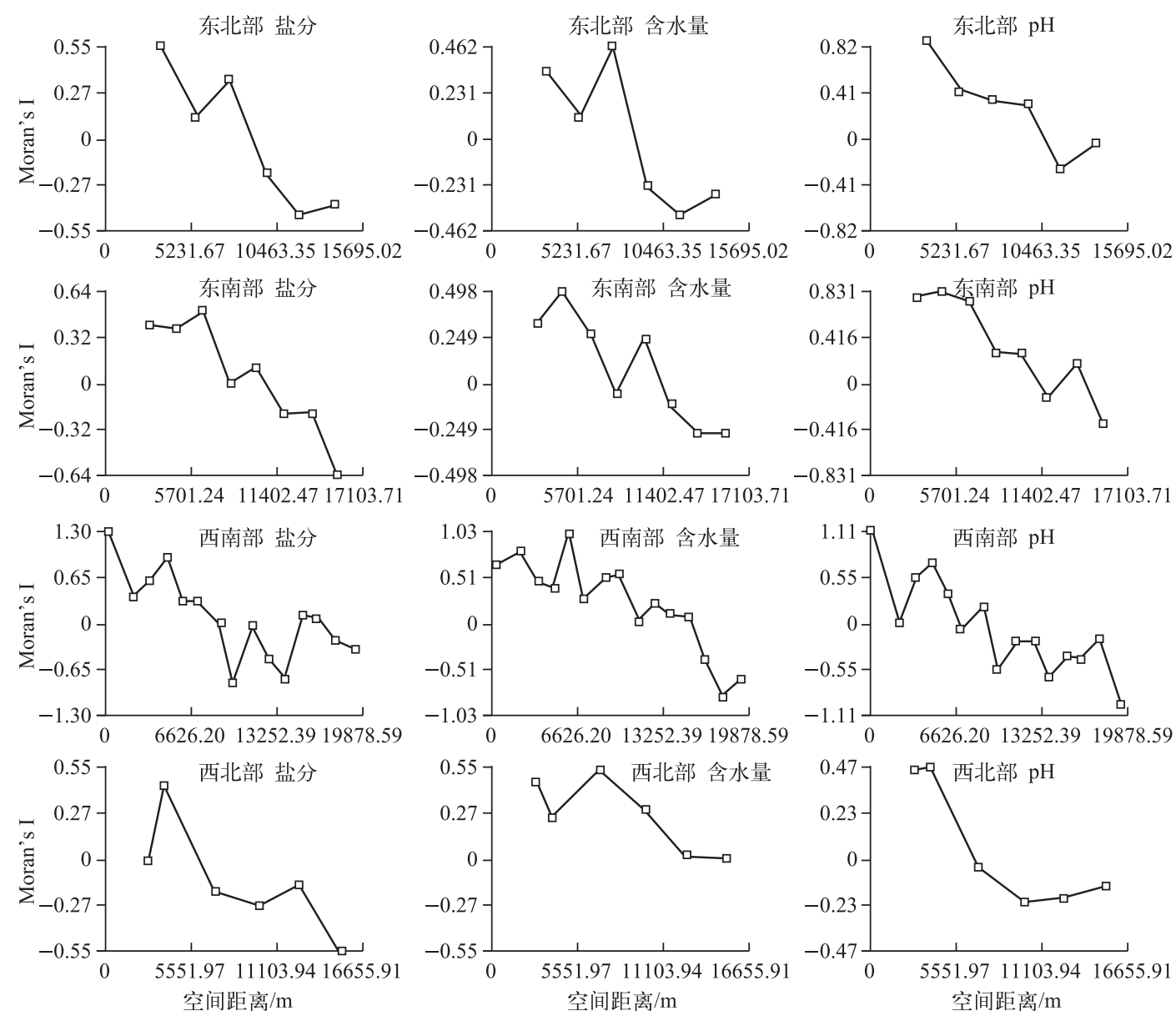

图 2 土壤盐分、含水量和 $\mathrm{pH}$ 的 Moran's I 系数

Fig.2 Moran's I analysis of soil salinity, moisture and $\mathrm{pH}$

\section{4 土壤水盐空间分布特征}

地统计学可根据半方差分析所确定的理论模型和已有的观测数据, 对未采样点进行空间插值, 其结果 平滑了采样点的数据, 使得大值降低、小值增高, 以图形的形式展示性状的空间异质性, 并且能够有助于辨 别空间分布格局 ${ }^{[23]}$. 通过普通克里金插值预测得到对离湖滨 5 15 km 绕湖一周 $160 \mathrm{~km}$ 范围内表层土壤盐 分、含水量与 $\mathrm{pH}$ 的空间分布可以看出 (图 3), 艾比湖湿地表层土壤盐分、含水量和 $\mathrm{pH}$ 的空间分布多呈现不 规则条带状格局. 采样区土壤盐分与 $\mathrm{pH}$ 具有一定程度的同步性, 即西北部高于东北部, 东南部高于西南部, 盐分高值区出现在西北部的石头房子管护站以及西南部阿奇克苏河下游, 低值区出现在东北部的大部分、 南部和西南部的精河和博河人湖河口处; $\mathrm{pH}$ 高值区出现在西北部石头房子管护站和东南部鳥鸟管护站区 域,低值区出现在东部奎屯河下游区域; 采样区土壤含水量北部和西南部明显要高于东部和西部, 高值区出 现在北部的科克巴斯陶管护站区域以及西南部引水围堰区; 对艾比湖湿地土壤盐分和 $\mathrm{pH}$ 进行相关性分析, 
可得土壤盐分与含水量和 $\mathrm{pH}$ 呈正相关, 相关性系数分别为 0.114 和 0.270 , 即在研究区内土壤盐分含量随土 壤含水量升高而增多, 土壤盐分含量高会导致土壤 $\mathrm{pH}$ 相应升高, 但是, 相关系数均较低, 并未呈现较好的线 性关系,这也说明了土壤盐分与含水量和 $\mathrm{pH}$ 关系的复杂性.
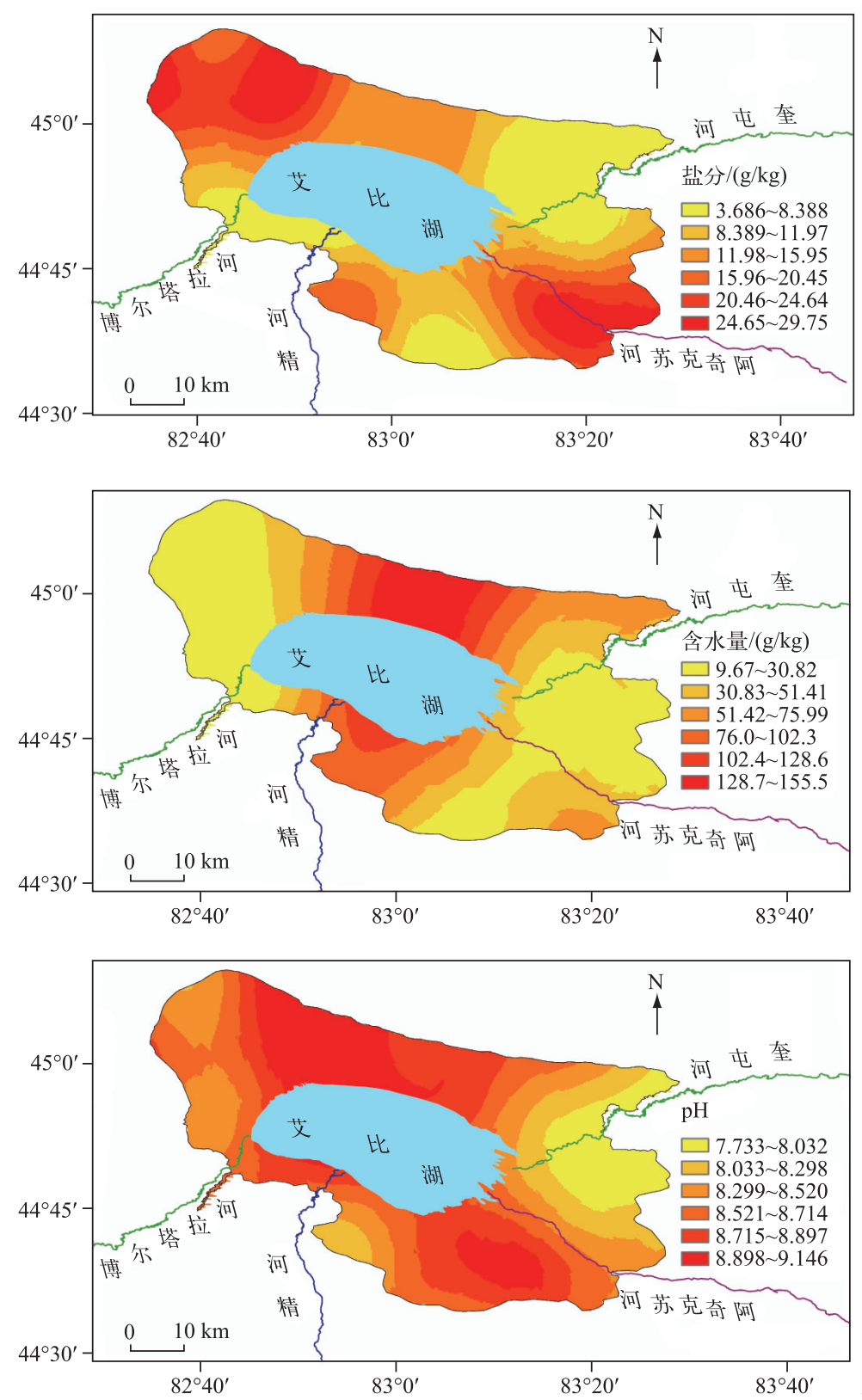

图 3 土壤盐分、含水量和 $\mathrm{pH}$ 空间分布

Fig.3 Spatial distributions of soil salinity, moisture and $\mathrm{pH}$

参照新疆土壤盐碱化分级标准, 分析研究区土壤盐渍化程度 (图 4), 结果表明艾比湖湿地东南部阿奇克 苏河下游和西北部石头房子管护站区域盐渍化程度最高, 已达到盐土程度; 东北部的奎屯河下游、南部沙泉 子区域以及精河人湖河口盐渍化程度较低, 属于非盐渍化土. 盐渍化分级盐土、重度盐化土、中度盐化土、轻 
度盐化土和非盐化土在研究区所占面积分别为 $568.394 、 537.848 、 319.026 、 473.306$ 和 $269.588 \mathrm{~km}^{2}$, 可见艾比 湖湿地土壤盐渍化盐土面积最大,重度盐化土次之.

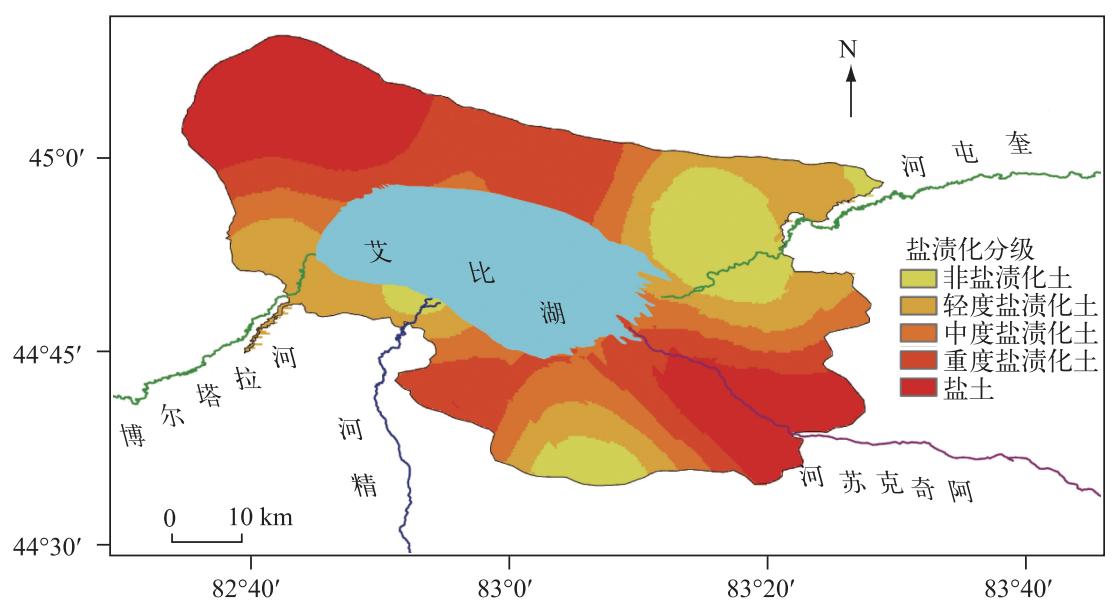

图 4 研究区土壤盐渍化分级空间分布

Fig.4 Spatial distribution of classification of soil salinization in the study area

\section{3 讨论}

以艾比湖湖心质点为中心, 对离湖滨 $5 \sim 15 \mathrm{~km}$ 绕湖一周 $160 \mathrm{~km}$ 范围内表层土壤水盐特征进行分析, 不 同区域上的土壤盐分、含水量和 $\mathrm{pH}$ 具有一定的空间变异性,其中不同区域的土壤盐分属于中等变异强度; 东北部、东南部、西南部的含水量属于中等变异强度, 而西北部属于强变异性; 不同区域的土壤 $\mathrm{pH}$ 均属于弱 变异强度, 这与贡璐等 ${ }^{[8]}$ 对干旱区土壤水盐空间变异的研究结论相似; 不同区域上土壤盐分、含水量与 $\mathrm{pH}$ 的块金值/基台值小于 0.25 ,与孔德庸等 ${ }^{[24]}$ 对新疆焉耆盆地土壤盐分 $(0 \sim 30 \mathrm{~cm})$ 空间变异特征研究结论相 同,均表现为强的空间相关性,这说明土壤盐分是结构性因素 (如地形、母质、土壤类型和气候等) 起主导作 用; 而与刘广明等 ${ }^{[25]}$ 对新疆准噶尔盆地南缘典型绿洲区盐分空间变异研究不同,后者得出土壤盐分的块金 值/基台值范围在 0.25 0.75, 表现为中等空间相关性, 盐分是由随机性因素 (如灌溉、耕作措施和土壤改良 等各种人为活动) 和结构性因素 (如气候、地形、土壤类型等) 共同主导引起的; 艾比湖湿地不同区域上的土 壤盐分、含水量与 $\mathrm{pH}$ 的分维数 $D$ 范围在 $1.033 \sim 1.881$ 之间, 这比赵锐锋等 ${ }^{[26]}$ 对塔里木河源流区绿洲土壤 $0 \sim 30 \mathrm{~cm}$ 含盐量分维数 $D$ 要小, 当随机因素差、结构性好, 则分维数低, 说明艾比湖湿地不同区域上的土壤 盐分、含水量与 $\mathrm{pH}$ 空间分异主要是由结构性因素引起的.

通过普通克里金插值得到艾比湖湿地土壤水盐空间分布特征,其中土壤盐分高值区出现在西北部的石 头房子管护站以及西南部阿奇克苏河下游区域,与土壤 $\mathrm{pH}$ 呈现出一定程度的同步性,西北部临近阿拉山大 风口, 常年风沙死掠, 在持续的强烈蒸发作用下, 下层土壤以及地下水中的可溶性盐分积聚于表层, 导致盐 分升高; 东南部处于阿拉山口径直通道上,盐尘使得艾比湖东南部原来的湿地景观演变形成为盐漠景观,位 于干涸湖底及其周围, 整个剖面的盐分含量很高 ${ }^{[27]}$, 已有研究表明地下水矿化度与土壤表层含盐量之间存 在正相关关系, 地下水埋深与土壤表层含盐量之间存在负相关关系 ${ }^{[28]}$, 而东南部阿奇克苏河和盐场 (6.79 $\mathrm{g} / \mathrm{L})$ 地下水矿化度较高 ${ }^{[29]}$, 在强烈的蒸发下, 土壤表层盐渍化严重, 黄昌勇 ${ }^{[30]}$ 也指出季节性积盐和脱盐交 替是土壤碱化和土壤 $\mathrm{pH}$ 变化的重要原因; 其次, 通过对艾比湖湿地土壤盐分和 $\mathrm{pH}$ 进行相关性分析, 可知土 壤盐分与含水量和 $\mathrm{pH}$ 呈正相关, 这与沈浩等 ${ }^{[31]}$ 对玛纳斯河流域农田土壤水盐空间分布特征及影响因素的 研究中表层土壤水盐含量呈正相关性相同, 即土壤盐分含量随土壤含水量升高而增多; 此外, 土壤盐分含量 的升高是导致土壤 $\mathrm{pH}$ 升高的原因之一, 这与杨劲松等 ${ }^{[5]}$ 对黄河三角洲地区土壤水盐空间变异特征研究中 土壤 $\mathrm{pH}$ 与盐分含量呈极显著负相关不同, 这可能是由于艾比湖湿地的地理位置和极端干旱的气候所致. 土 
壤盐分低值区出现在东北部的大部分、南部和西南部的精河和博河人湖河口处, 东北部以及奎屯河下游, 主 要植物群落为梭梭, 沙化较为严重, 土壤沙化的后果是土壤肥力降低、土壤颗粒变细、土壤盐分含量减少 ${ }^{[32]}$, 土壤含水量低, 南部人工种植梭梭的沙泉子, 土壤质地以砂砾为主, 持水能力差, 西南部有季节性河流精河 和博河, 且精河下游人湖河口进行的人工引水围堰工程和养殖水产工程不仅对土壤质地起到了良好的改善 作用, 使得土壤保水能力加强, 盐分含量相对降低; 博河下游含水量较低是由土壤质地差异引起的; 土壤含 水量高值区出现在北部的科克巴斯陶管护站区域以及西南部引水围堰区, 北部的科克巴斯陶管护站区域海 拔地势条件较东部地区要低, 有天然泉水外流, 含水量较东部高, 采样期 8 月正值旱季, 所以研究区大部分 地区含水量都比较低.

通过对艾比湖湿地土壤盐渍化分析可知, 研究区土壤盐渍化以盐土面积最大, 重度盐化土次之, 这与金 海龙等 ${ }^{[10]}$ 在 2009 年研究发现以重度盐化土为主的艾比湖湿地不同, 说明艾比湖湿地近几年土壤已由重度 盐化土转向盐土, 土壤盐渍化日益严重. 通过研究艾比湖湿地土壤水盐空间分布特征, 可为绿洲土地的合理 开发利用和土壤盐渍化的防治改良提供理论参考。

\section{4 结论}

1) 绕湖一周不同区域的土壤盐分均属中等变异强度;土壤含水量在西北部属强变异性,而东北、东南和 西南部均属中等变异强度; 土壤 $\mathrm{pH}$ 在不同区域内均属弱变异强度.

2) 通过半方差函数分析, 除了西北部土壤盐分比较符合球状模型外, 其它不同区域土壤盐分、含水量和 $\mathrm{pH}$ 半方差理论模型都比较符合高斯模型; 不同区域上的土壤盐分、含水量与 $\mathrm{pH}$ 的空间分布都是由结构性 因素 (如地形、母质、气候和土壤类型等) 起主导作用; Moran's I 系数分析表明西南部土壤盐分、含水量和 $\mathrm{pH}$ 的 Moran's I 系数比其它方位的波动较大, 空间相关性较强, 这与气候、地貌、微地形、土壤类型等因素密切 相关.

3) 研究区表层土壤盐分、含水量和 $\mathrm{pH}$ 的空间分布多呈现不规则条带状格局. 土壤盐渍化程度以盐土面 积最大, 重度盐化土次之.

致谢: 感谢张小萌师兄、王盼盼师姐、杜改俊师姐、马雯在野外采集样品与室内实验分析所做的指导与帮助.

\section{5 参考文献}

[ 1 ] Wang Zhuoran, Zhao Gengxing, Gao Mingxiu et al. Characteristis of soil water and salt spatial variations in the spring season in typical Yellow River delta areas of Kenli County, China. Journal of Agricultural Resources and Environment, 2015, 32(2) : 154-161 (in Chinese with English abstract). [王卓然, 赵庚星, 高明秀等. 黄河三角洲典型地区春季土壤水 盐空间分异特征研究——以旺利县为例. 农业资源与环境学报, 2015, 32(2): 154-161. ]

[ 2 ] Jordán MM, Navarro-Pedreño J, García-Sánchez E et al. Spatial dynamics of soil salinity under arid and semi-arid conditions gelogical and environmental implieations. Environmental Geology, 2004, 45: 448-456.

[ 3 ] Herbst M, Diekkruger B. Modelling the spatial variability of soil moisture in micro-scale catehment and comparison with field data using geostatisties. Physics and Chemisty of the Earth, 2003, 8: 239-245.

[ 4 ] Cemek B, Gnler M, Kilic K et al. Assessment of spatial variability in some soil properties as related to soil salinity and alkalinty in Bafra plain in northern Turkey. Environmental Monitoring and Assessment, 2007, 124: 223-234.

[ 5 ] Yang Jingsong, Yao Rongiang. Spatial variability of soil water and salt characteristics in the Yellow River delta. Scientia Geographica Scinica, 2007, 27(3) : 348-353(in Chinese with English abstract). [杨劲松, 姚荣江. 黄河三角洲地区土 壤水盐空间变异特征研究. 地理科学, 2007, 27(3): 348-353.]

[ 6 ] Zhang Bo, Meng Bao, Hao Jianxiu et al. Heterogeneity of soil moisure and salt contents and its eco-environmental effects in oasis-desert belt in arid zone-taking Zhangye Oasis in the middle reaches of Heihe River as a case study. Journal of Desert Research, 2006, 26(1) : 81-84(in Chinese with English abstract). [张勃, 孟宝, 郝建秀等. 干旱区绿洲-荒漠带土壤 水盐异质性及生态环境效应研究——以黑河中游张掖绿洲为例. 中国沙漠, 2006, 26(1): 81-84.]

[ 7 ] Lü Guohong, Zhou Li, Jia Qingyu et al. Study on soil water and salt contents for main vegetation communities in the Liaohe Delta. Journal of Meteorology and Environment, 2010, 26(6): 65-70(in Chinese with English abstract). [吕国红, 周 莉, 贾庆宇等. 辽河三角洲主要植被类型土壤水盐含量研究. 气象与环境学报, 2010, 26(6) : 65-70.] 
[ 8 ] Gong Lu, Han Li, Ren Manli et al. Spatial variability of soil water-salt in a typical oasis on the upper reaches of the Tarim River. Journal of Soil and Water Conservation, 2012, 26(4) : 251-255, 278(in Chinese with English abstract). [贡璐, 韩丽，任曼丽等. 塔里木河上游典型绿洲土壤水盐空间分异特征. 水土保持学报, 2012, 26(4) : 251-255, 278.]

[ 9 ] Luo Geping, Zhang Baiping. Sustainable land use models for arid lands:A case study of the Northern Tianshan Mountain Areas. Acta Geographica Sinica, 2006, 61(11) : 1160-1170( in Chinese with English abstract). [罗格平, 张百平. 干旱 区可持续土地利用模式分析: 以天山北坡为例. 地理学报, 2006, 61(11)：1160-1170.]

[10] Jin Hailong, Bai Xiang, Man Zhonglong et al. Space different of soil in Xinjiang Lake Ebinur Wetland Natural Reserve District. Journal of Arid Land Resources and Environment, 2010, 24(2) : 150-157 (in Chinese with English abstract). [ 金 海龙, 白祥, 满中龙等. 新疆艾比湖湿地自然保护区土壤空间异质性研究. 干旱区资源与环境, 2010, 24(2): 150-157.]

[11] Ran Qiyang, Lü Guanghui, Wei Xuefeng et al. Enzyme activities and physicochemical properties of soils in the Lake Ebinur Nature Reserve in Xinjiang, China. Arid Zone Research, 2014, 31(4) : 715-722( in Chinese with English abstract). [再启洋, 吕光辉, 魏雪峰等. 艾比湖自然保护区土壤酶活性及理化性质. 干旱区研究, 2014, 31(4): 715-722.]

[12] Yang Jianjun, Lü Guanghui, Zhang Yan et al. Research on soil respiration of different plant communities in Lake Ebinur Basin. Xinjiang Agricultural Sciences, 2009, 46(2) : 223-231(in Chinese with English abstract). [杨建军, 吕光辉, 张 燕等. 艾比湖流域土壤呼吸日变化及水热因子影响. 新疆农业科学, 2009, 46(2): 223-231.]

[13] Yang Xiaodong, Fu Deping, Yuan Yue et al. Analysis on interspecific relationship of the dominant plant species in the Lake Ebinur Wetland Nature Reserve, Xinjiang. Arid Zone Research, 2010, 27(2) : 249-256(in Chinese with English abstract). [ 杨晓东, 傅德平, 袁月等. 新疆艾比湖湿地自然保护区主要植物的种间关系. 干旱区研究, 2010, 27(2) : 249-256. ]

[14] Li Lei, Li Yanhong, Chen Chengheri et al. Change of Lake Ebinur area during 1972-2011. Wetland Science, 2014,12 (2)：263-268( in Chinese with English abstract). [李磊, 李艳红, 陈成贺日等. 1972 2011 年期间艾比湖面积变化 研究. 湿地科学, 2014, 12(2): 263-268.]

[15] Bao Shidan ed. Soil agricultural chemistry analysis. Beijing: China Agriculture Press, 2005(in Chinese). [鲍士旦. 土壤 农化分析. 北京: 中国农业出版社, 2005.]

[16] Xinjiang Department of Agriculture, Xinjiang Soil Survey Office eds. The soil of Xinjiang. Beijing: Science Press, 1996 : 151-521 (in Chinese). [ 新疆农业厅, 新疆土壤普查办公室. 新疆土壤. 北京: 科学出版社, 1996:151-521.]

[17] Hu Kelin, Li Baoguo, Lin Qimei et al. Spatial variability of soil nutrient in wheat field. Transactions of the Chinese Society of Agricultural Engineering, 1999, 15(3) :33-38(in Chinese with English abstract). [胡克林, 李保国, 林启美等. 农 田土壤养分的空间变异性特征. 农业工程学报, 1999, 15(3): 33-38. ]

[18] Wang Zhengquan ed. Application of geostatistics in ecology. Beijing: Science Press, 1999: 162-192(in Chinese). [王政 权. 地统计学及其在生态学中的应用. 北京: 科学出版社, 1999: 162-192.]

[19] Song Xinshan, He Yan, Wang Yonghui. Theories and application of salt distribution field in water-soil environment on study of soil salination in Songnen Plain. Scientia Geographica Scinica, 2003, 23(1) : 72-76( in Chinese with English abstract). [ 宋新山, 何岩, 汪永辉. 水土化学场理论在松嫩平原盐渍土研究中的应用. 地理科学, 2003, 23(1): 72-76.]

[20] Liu Fucheng, Shi Xuezheng, Pan Xianzhang et al. Characteristics of spatial variability of total phosphorus in soil of the typical area of Taihu Lake watershed. Scientia Geographica Scinica, 2003, 23(1) : 77-81(in Chinese with English abstract). [刘付程, 史学正, 潘贤章等. 太湖流域典型地区土壤磷素含量的空间变异特征. 地理科学, 2003, 23(1): 77-81.]

[21] Jia Xiaohong, Li Xinrong, Zhou Haiyan et al. Spatial heterogeneity analysis of soil property at plough horizon of farm land by irrigating using Yellow River in arid desert region. Journal of Soil and Water Conservation, 2005, 19(5) : 101-104(in Chinese with English abstract). [贾晓红, 李新荣, 周海燕等. 黄灌沙区农田耕层土壤性状空间异质性分析. 水土保 持学报, 2005, 19(5): 101-104.]

[22] Hu Wei, Shao Ming'an, Wang Quanjiu. Scale-dependency of spatial variability of soilmoisture on a degraded slope-land on the Loess Plateau. Transactions of the Chinese Society of Agricultural Engineering, 2005, 21(8) : 11-16(in Chinese with English abstract). [胡伟, 邵明安, 王全九. 黄土高原退耕坡地土壤水分空间变异的尺度性研究. 农业工程学报, $2005,21(8): 11-16$. 
[23] Zhang CS, Mcgrath D. Geostatistical and GIS analyses on soil organic carbon concentrations in grassland of southeastern Ireland from two different periods. Geoderma, 2004, 119: 261-275.

[24] Kong Deyong, Sheng Jiandong, Wu Hongqi et al. Spatial variability analysis of soil salinity in Yanqi Basin, Xinjiang. Journal of Irrigation and Drainage, 2009, 28(2): 124-126(in Chinese with English abstract). [ 德庸, 盛建东, 武红旗 等. 新疆焉耆盆地土壤盐分空间变异特征分析研究. 灌溉排水学报, 2009, 28(2): 124-126. ]

[25] Liu Guangming, Lü Zhenzhen, Yang Jingsong et al. Spatial variation characteristics of soil salinity in typical oasis region. Transactions of the Chinese Society of Agricultural Engineering, 2012, 28(16): 100-107 (in Chinese with English abstract). [刘广明, 吕真真, 杨劲松等. 典型绿洲区土壤盐分的空间变异特征. 农业工程学报, 2012, 28(16): 100-107.]

[26] Zhao Ruifeng, Chen Yaning, Hong Chuanxun. Study on spatial variability and pattern of soil salinity of the oasis in the headstreams of the Tarim River Basin: A case study on Yuepuhu oasis. Geographical Research, 2008, 27(1):135-144(in Chinese with English abstract). [ 赵锐锋, 陈亚宁, 洪传勋. 塔里木河源流区绿洲土壤含盐量空间变异和格局分 析一以岳普湖绿洲为例. 地理研究, 2008, 27(1):135-144.]

[27] Jilili Abuduwaili, Xu Junrong, Mu Guijin et al. Effect of soil dust from Lake Ebinur on soil salts and landscape of surrounding regions. Journal of Glaciology and Geocryology, 2007, 29(6):928-939(in Chinese with English abstract). [吉 力力 . 阿不都外力 , 徐俊荣, 穆桂金等. 艾比湖盐尘对周边地区土壤盐分及景观变化的影响. 冰川冻土, 2007, 29 (6) :928-939.]

[28] Sun Jian, Qiao Ying, Zhu Zhu et al. The groundwater dynamic changes and its effect on secondary salinization of soil-A case of regiment 224 in xinjiang production and construction crops. Hubei Agricultural Sciences, 2012, 51(9) : 1763-1766 (in Chinese with English abstract). [孙建, 乔英, 朱珠等. 地下水动态及与土壤盐渍化的关系一一新疆兵团二二 四团场为例. 湖北农业科学, 2012, 51(9): 1763-1766.]

[29] Zhao Feng. Analysis on the driving mechanism of arid oasis stability-Taking the Aibi Lake Watershed as anexample. Journal of Xinjiang Normal University: Natural Sciences Edition, 2007, 26(3) :186-189(in Chinese with English abstract). [赵枫. 艾比湖湿地自然保护区阿其克苏河北岸地下水矿化度研究. 新疆师范大学学报: 自然科学版, 2007, 26 (3) : 186-189.]

[30] Huang Changyong ed. Pedometrics. Beijing: China Agriculture Press, 2000( in Chinese). [黄昌勇. 土壤学. 北京: 中国 农业出版社, 2000.]

[31] Shen Hao, Jilili Abuduwaili. Spatial distribution of soil moisture and salinity and their influence factors in the farmland of Manas River catchment, Northwest China. Chinese Journal of Applied Ecology, 2015, 26(3) : 769-776 (in Chinese with English abstract). [沈浩, 吉力力. 阿不都外力. 玛纳斯河流域农田土壤水盐空间分布特征及影响因素. 应用生态 学报, 2015, 26(3): 769-776.]

[32] Xia Xuncheng, Hu Wenkang. Resources and environment of Taklimakan Desert. Scinence in China: Series B, 1993, 23 (8) : 889-896( in Chinese with English abstract). [夏训诚, 胡文康. 塔克拉玛干沙漠资源与环境. 中国科学: B 辑, $1993,23(8): 889-896$. 